\title{
Shock Index (SI) dan Modified Shock Index (MSI) sebagai prediktor Outcome pada Pasien Gawat Darurat: Systematic Review
}

\author{
Zulkifli B. Pomalango \\ Program Studi Ilmu Keperawatan Universitas Negeri Gorontalo \\ Email : zulkifli@ung.ac.id
}

\begin{abstract}
Abstrak
Shock Index dan Modified Shock Index merupakan parameter non invasif dapat digunakan dalam pemantauan status hemodinamika pasien untuk menilai hasil klinis dan memprediksi mortalitas pasien gawat darurat, sehingga dapat membantu penatalaksanaan pada waktu yang tepat terutama dalam pelaksanaan triase di departemen darurat. Penelitian ini bertujuan untuk mengetahui penggunaan parameter Shock Index dan Modified Shock Indeks dalam memprediksi hasil klinis pasien gawat darurat, mengetahui perbandingan penggunaan parameter Shock Index, Modified Shock Indeks dengan Tekanan Darah, Nadi untuk memprediksi hasil klinis pasien gawat darurat dan mengetahui hasil statistik penelitian tentang Shock Index dan Modified Shock Indeks sebagai parameter yang efektif untuk memprediksi hasil klinis pasien gawat darurat. Pencarian artikel jurnal menggunakan kerangka PICO (Population: Pasien gawat darurat, Intervention: parameter Shock Index dan Modified Shock Indeks, Comparison Intervention: Nadi, Tekanan Darah, Outcome: Parameter sederhana untuk mengidentifikasi kondisi pasien gawat darurat. Delapan artikel yang dianalisis dengan rentang waktu antara 2007-2017 (10 tahun), jumlah sampel \pm 74.512 . Hasilnya menunjukkan secara keseluruhan artikel menyebutkan bahwa Shock Index dan Modified Shock Indeks dapat dan mudah digunakan dalam memprediksi hasil klinis pasien gawat darurat. Shock Index dan Modified Shock Indeks signifikan berkorelasi dengan penanda resiko yang akurat, berupa kematian klinis pada pasien dengan kondisi darurat dan lebih baik dari pada tekanan darah dan detak jantung. Sehingga SI dan MSI dapat direkomendasikan sebagai paramater non invasif guna mendeteksi lebih awal status hemodinamik pasien dan dapat digunakan dalam triase pasien di ruang gawat darurat.
\end{abstract}

Kata kunci: Shock Index, Modified Shock Index, Prediktor Outcome Emergency Patient

\begin{abstract}
To determine the use of the Shock Index and Modified Shock Index parameters in predicting clinical outcomes of patients in the emergency department, to find out the comparison of the use of Shock Index parameters, Modified Shock Index with Blood Pressure, Pulse to predict the clinical outcome of emergency patients and to find out the statistical results research on Shock Index and Modified Shock Index as effective parameters for predicting clinical outcomes of emergency patients. Search journal articles using the PICO framework (Population: Emergency patients, Intervention: parameters Shock Index and Modified Shock Index, Comparison Intervention: Pulse, Blood Pressure, Outcome: Simple parameters for identifying emergency patient conditions. Eight articles were analyzed with a span of time between 2007-2017 (10 years), the number of samples was \pm 74,512. The results show that the overall article states that the Shock Index and Modified Shock Index can and are easily used in predicting the clinical outcomes of emergency patients. Shock Index and Modified Shock Index significantly correlated with accurate risk markers, clinical death in emergency patients and better than blood pressure and heart rate. So that SI and MSI can be recommended as non-invasive parameters to detect earlier the hemodynamic status of the patient and can be used in triage of patients in the emergency department.
\end{abstract}

Keywords: Shock Index, Modified Shock Index, Prediktor Outcome Emergency Patient

\section{Pendahuluan}

Shock Index (SI) dan Modified Shock

Index (MSI) merupakan parameter non

invasif yang dapat digunakan dalam

pemantauan status hemodinamika pasien

untuk menilai hasil klinis dan memprediksi mortalitas pasien gawat darurat, sehingga dapat membantu penatalaksanaan pada waktu yang tepat terutama dalam pelaksanaan triase di departemen darurat (Jevon \& Ewens, 2009). Beberapa penelitian telah 
didapatkan SI dan MSI merupakan prediktor klinis yang lebih baik dari pada nadi dan tekanan darah (Liu et al., 2012). Namun SI dan MSI belum banyak digunakan dalam pemeriksaan status hemodinamik pasien. Pasien dengan outcome masuk ICU memiliki waktu yang panjang, karena kurangnya ketepatan dalam mengidentifikasi status hemodinamik pasien.

SI merupakan nilai yang didapatkan dari perhitungan sederhana Heart Rate (HR) dibagi dengan tekanan darah Systolic Blood Pressure (SBP), digunakan untuk mengevalusi stabilitas hemodinamik pasien akut. Peningkatan SI mengindikasikan output ventrikel kiri menurun, jika hal ini terjadi terus menerus dapat menyebabkan mortalitas (Torabi, Mirafzal, Rastegari, \& Sadeghkhani, 2016). SI digunakan dalam memprediksi tingkat keparahan syok hipovolemik (Birkhahn, Gaeta, Terry, Bove, \& Tloczkowski, 2005). Sejumlah penelitian telah mengungkapkan manfaat penggunaan SI dalam menilai hasil klinis dan memprediksi angka mortalitas pada pasien trauma, memprediksi angka mortalitas pada pneumonia, memprediksi kehamilan ektopik yang pecah, kategorisasi pasien emboli paru, dan memprediksi prognosis pada infark miokard akut.
MSI merupakan nilai yang didapatkan dari Heart Rate (HR) dibagi dengan Mean Arterial Pressure (MAP). Nilai MSI yang meningkat mengindikasikan nilai stroke volume dan resistensi pembuluh darah sistemik, mencerminkan keadaan sirkulasi hipodinamik. Sedangkan jika nilai MSI menurun menunjukkan bahwa SI dan SVR tinggi, pasien dalam keadaan hiperdinamik, yang menandakan kondisi yang serius. Dan nilai MSI memprediksi tingkat mortalitas secara signifikan lebih baik daripada denyut jantung, tekanan darah sistolik, DBP dan SI (Singh, Ali, Agarwal, \& Srivastava, 2014).

Berdasarkan hasil penelitian terkait nilai prognostik SI dan MSI, terdapat perbedaan nilai prognostik dari hasil penelitian. Untuk itu penulis tertarik melakukan tinjauan sistematis dari penggunaan parameter SI dan MSI sebagai prediktor outcome pada pasien gawat darurat.

\section{Metode}

Pencarian artikel jurnal menggunakan kerangka PICO (Population: Pasien gawat darurat, Intervention: parameter Shock Index (SI) dan Modified Shock Indeks (MSI), Comparison Intervention: Nadi, Tekanan Darah, Outcome: Parameter sederhana untuk mengidentifikasi kondisi pasien gawat darurat. 


\section{Pertanyaan Penelitian}

Pertanyaan yang dibahas dalam systematic review ini, yaitu :

1. Apakah Shock Index dan Modified Shock Indeks merupakan parameter yang efektif untuk memprediksi hasil klinis pasien gawat darurat?

2. Apakah Shock Index dan Modified Shock Indeks lebih baik dari Tekanan Darah dan Nadi untuk memprediksi hasil klinis pasien gawat darurat?

3. Bagaimanakah hasil statistik penelitian tentang Shock Index dan Modified Shock Indeks sebagai parameter yang efektif untuk memprediksi hasil klinis pasien gawat darurat?

\section{Strategi Pencarian}

Tinjauan literatur mengumpulkan artikel dalam rentan tahun 2007-2017 dalam database Proquest, ScientDirect, EBSCO, Google Scholar. Pencarian dilakukan dengan menggunakan kata kunci "Shock Index", "Modified Shock Index", "Prediktor Outcome Emergency Patient".

\section{Kelayakan (Inklusi/ ekslusi)}

Artikel yang digunakan hubungan antara nilai prognostik SI dan MSI dengan hasil klinis pasien dan kematian klinis pasien di Departemen Gawat Darurat. Tidak memasukkan artikel yang pembahasannya hanya tersedia diabstrak.

\section{Ekstraksi Data}

Empat variabel yang terdiri MSI, SI, Nadi dan tekanan darah diurutkan dan diekstraksi informasi tentang rincian artikel, terdiri atas penulis, tahun, desain penelitian, ukuran sampel, demografi pasien, nilai MSI, SI, Nadi dan Tekanan Darah

\section{Hasil}

Hasil utama untuk analisis ini adalah prediksi outcome dan mortalitas pada pasien gawat darurat berdasarkan nilai $P$ Value, Odds Ratio (OR), Confidence Interval (CI), nilai sensivitas, nilai spesifisitas dan AUROC curve.

\section{Seleksi dan Pengambilan Artikel}

Menganalisis artikel yang relevan menggunakan JBI tools dalam mengidentifikasi kelayakan artikel yang akan digunakan berdasarkan judul dan tujuan yang dibahas dalam systematic review. 

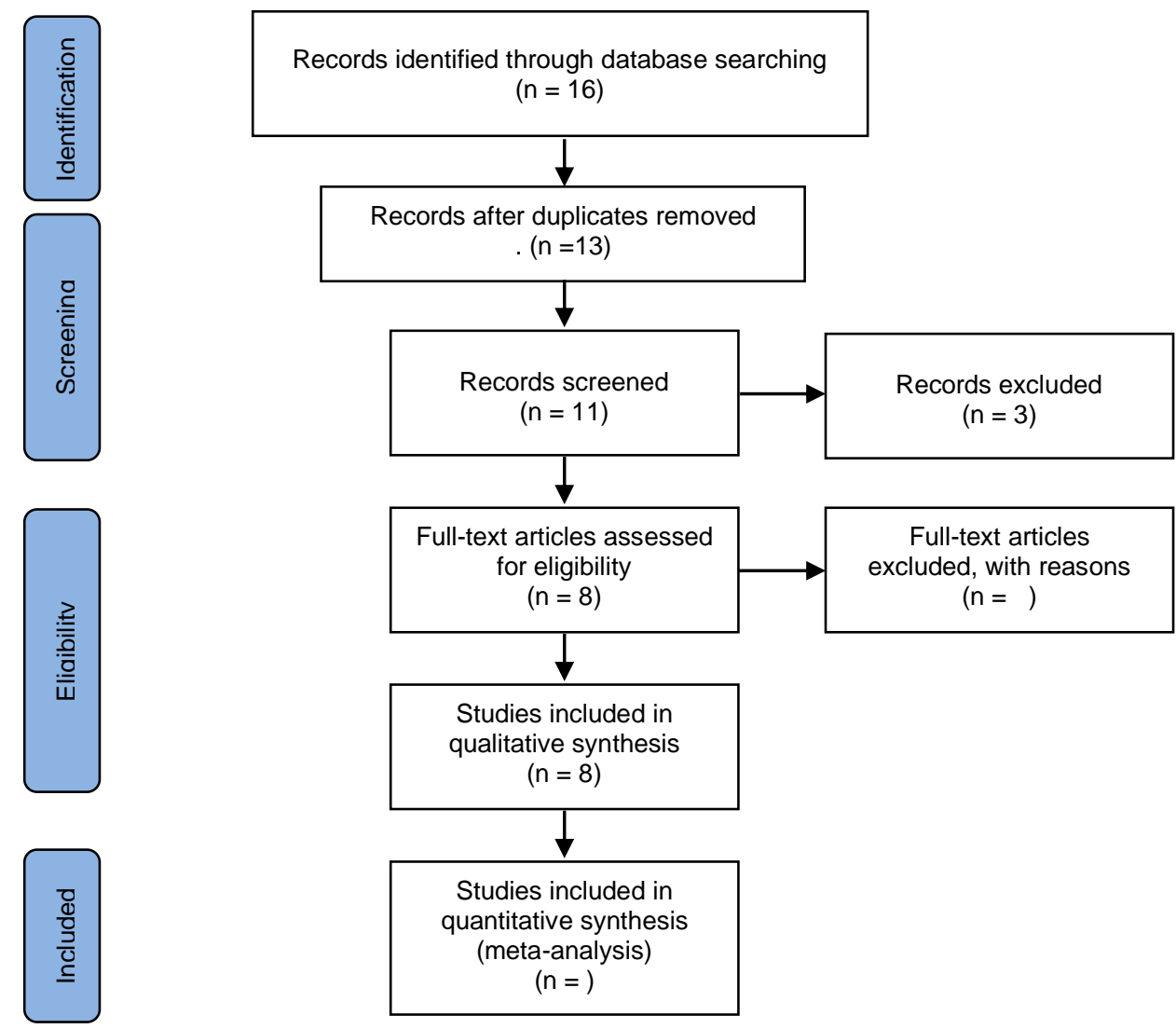

\section{Gambar 1. Prisma Flow Chart}

\section{Hasil}

Enam belas kutipan yang diambil dari pencarian database dan skrining referensi, beberapa artikel dikeluarkan karena tidak relevan dan terdapat beberapa artikel yang berganda. Dari tiga belas artikel yang tersisa, terdapat lima artikel yang dikeluarkan karena tidak sesuai dengan variabel yang dibahas, tinjauan literatur dalam bentuk systematic review, dan tidak memenuhi kriteria populasi dan sampel.
Berdasarkan seleksi akhir, terdapat 8 artikel yang akhirnya dimasukkan dalam review sistemik, dengan jumlah sampel \pm 74.512. Dari 8 artikel tersebut diekstrasi dalam tabel 1 dan deskripsi studi penggunaan SI dan MSI terhadap outcome dan prediktor mortalitas pada pasien gawat darurat dicantumkan dalam tabel 2 dan tabel 3. 


\begin{tabular}{|c|c|c|c|c|c|c|}
\hline No & Author \& Year & Title & Level JBI & Purpose & $\begin{array}{c}\text { Method } \\
\text { (Design, Sample, Data } \\
\text { Analysis, Instument) }\end{array}$ & $\begin{array}{l}\text { Major } \\
\text { Finding }\end{array}$ \\
\hline 1 & $\begin{array}{l}\text { Yecheng L, } \\
\text { Jihai L, Zhe } \\
\text { A.F, Guang L.S, } \\
\text { Jun X, Zhi W, } \\
\text { Hua Z, Zhong } \\
\text { W, Xue Y } \\
2012\end{array}$ & $\begin{array}{l}\text { Modified } \\
\text { Shock Index } \\
\text { and Mortality } \\
\text { rate of } \\
\text { emergency } \\
\text { patient }\end{array}$ & $\begin{array}{l}\text { Level 3.c } \\
\text { Cohort study } \\
\text { with control } \\
\text { group }\end{array}$ & $\begin{array}{l}\text { Untuk mengetahui } \\
\text { apakah Modified } \\
\text { Shock Index (MSI) } \\
\text { prediktor mortalitas } \\
\text { lebih baik dari denyut } \\
\text { jantung, tekanan } \\
\text { darah dan Shock } \\
\text { Index (SI) pada } \\
\text { pasien darurat }\end{array}$ & $\begin{array}{l}\text { Design: Kohort } \\
\text { retrospektif, observasi } \\
\text { study } \\
\text { Sample: } 22.161 \text { pasien } \\
\text { Data Analysis: Analisis } \\
\text { regresi logistik multivariat } \\
\text { Instrumen: Lembar } \\
\text { Observasi }\end{array}$ & $\begin{array}{l}\text { MSI lebih besar dari } 1,3 \text { ada } \\
\text { kemungkinan peningkatan masuk } \\
\text { ICU. MSI adalah prediktor klinis } \\
\text { yang lebih penting dari pada tekanan } \\
\text { darah dan Nadi. Selain itu, MSI }>1,3 \\
\text { merupakan prediktor peningkatan } \\
\text { mortalitas. Hal ini sering terlihat } \\
\text { pada pasien dengan penyakit } \\
\text { serebrovaskular, nyeri dada dan } \\
\text { jantung berdebar } \\
\text { (Liu et al., 2012) }\end{array}$ \\
\hline 2 & $\begin{array}{l}\text { Qing S, Jing } \\
\text { S.X, Hai S, Ju } \\
\text { Xiang L, } \\
\text { Wenying W, } \\
\text { Kui H, Xiao S.C } \\
2015\end{array}$ & $\begin{array}{l}\text { Modified } \\
\text { Shock Index is } \\
\text { a Predictor for } \\
7 \text { Day } \\
\text { Outcomes in } \\
\text { Patients with } \\
\text { STEMI }\end{array}$ & $\begin{array}{l}\text { Level 3.c } \\
\text { Cohort study } \\
\text { with control } \\
\text { group }\end{array}$ & $\begin{array}{l}\text { Untuk } \\
\text { membandingkan nilai } \\
\text { prediksi Modified } \\
\text { Shock Index (MSI) } \\
\text { dan Shock Index (SI) } \\
\text { selama } 7 \text { hari pada } \\
\text { pasien dengan Infark } \\
\text { Miokard ST-segmen } \\
\text { elevasi (STEMI) }\end{array}$ & $\begin{array}{l}\text { Design: Kohort } \\
\text { retrospektif, observasi } \\
\text { study } \\
\text { Sample: } 160 \text { rekam medis, } \\
\text { Data Analysis: } \\
\text { Menggunakan uji t } \\
\text { berpasangan atau wilcoxon } \\
\text { digunakan untuk } \\
\text { menentukan perbedaan } \\
\text { variebal kontinu antar } \\
\text { kelompok. } \\
\text { Pearson } X^{2} \text { untuk penyajian } \\
\text { variabel kategori dalam } \\
\text { bentuk presentase } \\
\text { Instrumen: Lembar } \\
\text { Observasi }\end{array}$ & $\begin{array}{l}\text { Kedua parameter SI dan MSI di } \\
\text { gawat darurat bisa memprediksi } \\
\text { angka mortalitas dan MACE dalam } \\
\text { waktu } 7 \text { hari pada pasien dengan } \\
\text { STEMI, tetapi MSI lebih akurat } \\
\text { daripada SI, karena MSI lebih dapat } \\
\text { mencerminkan perfusi dan resistensi } \\
\text { vaskuler sistemik } \\
\text { (Shangguan et al., 2015) }\end{array}$ \\
\hline 3 & $\begin{array}{l}\text { Mehdi T, } \\
\text { Amirhossein M, } \\
\text { Azam R, Neda } \\
\text { S } \\
2015\end{array}$ & $\begin{array}{l}\text { Association of } \\
\text { triage time } \\
\text { Shock Index, } \\
\text { Modified } \\
\text { Shock Index } \\
\text { and Age } \\
\text { Shock Index } \\
\text { with Mortality } \\
\text { in Emergency } \\
\text { Severity Index } \\
\text { level } 2 \\
\text { patients }\end{array}$ & $\begin{array}{l}\text { Level 3.c } \\
\text { Cohort study } \\
\text { with control } \\
\text { group }\end{array}$ & $\begin{array}{l}\text { Untuk } \\
\text { membandingkan } \\
\text { mortalitas dan } \\
\text { perkiraan perawatan } \\
\text { unit perawatan } \\
\text { intensif (ICU) pada } \\
\text { waktu triase } \\
\text { menggunakan } \\
\text { parameter SI, MSI } \\
\text { dan Age SI, Tekanan } \\
\text { Darah dan Nadi } \\
\text { dengan ESI tingkat } 2\end{array}$ & $\begin{array}{l}\text { Design: Kohort } \\
\text { retrospektif, observasi } \\
\text { study } \\
\text { Sample: } 1285 \text { rekam } \\
\text { medis, } \\
\text { Data Analysis: Analisis } \\
\text { univariat dan multivariat } \\
\text { Instrumen: Lembar } \\
\text { Observasi }\end{array}$ & $\begin{array}{l}\text { Pada pasien dewasa non trauma, } \\
\text { waktu triase SI, MSI, dan Age SI } \\
\text { lebih baik dari tekanan darah untuk } \\
\text { prediksi mortalitas pada ESI tingkat } \\
\text { 2. Parameter tersebut daoat } \\
\text { digunakan sendiri atau } \\
\text { dikombinasikan } \\
\text { (Torabi, Mirafzal, Rastegari, \& } \\
\text { Sadeghkhani, 2015) }\end{array}$ \\
\hline 4 & $\begin{array}{l}\text { Mehdi T, } \\
\text { Shahrz M, } \\
\text { Amirhossein M, } \\
\text { Azam R, Neda } \\
\text { S } \\
2016\end{array}$ & $\begin{array}{l}\text { Shock Index, } \\
\text { modified } \\
\text { shock index, } \\
\text { and age shock } \\
\text { index for } \\
\text { prediction of } \\
\text { mortality in } \\
\text { Emergency } \\
\text { Severity Index } \\
\text { level } 3\end{array}$ & $\begin{array}{l}\text { Level 3.c } \\
\text { Cohort study } \\
\text { with control } \\
\text { group }\end{array}$ & $\begin{array}{l}\text { Untuk } \\
\text { membandingkan } \\
\text { mortalitas dan } \\
\text { perkiraan perawatan } \\
\text { unit perawatan } \\
\text { intensif (ICU) pada } \\
\text { waktu triase } \\
\text { menggunakan } \\
\text { parameter SI, MSI } \\
\text { dan Age SI, Tekanan } \\
\text { Darah dan Nadi } \\
\text { dengan ESI pada } \\
\text { tingkat } 3\end{array}$ & $\begin{array}{l}\text { Design: Kohort } \\
\text { retrospektif, observasi } \\
\text { study } \\
\text { Sample: } 3375 \text { rekam } \\
\text { medis, pasien non trauma } \\
\text { berusia diatas } 14 \text { tahun } \\
\text { yang dirawat di ED dengan } \\
\text { tingkat triase ESI tingkat } 3 \\
\text { Data Analysis: Analisis } \\
\text { univariat dan multivariat } \\
\text { Instrumen: Lembar } \\
\text { Observasi }\end{array}$ & $\begin{array}{l}\text { Pada pasien dewasa non trauma, } \\
\text { waktu triase SI, MSI, dan Age, } \\
\text { Tekanan Darah dan Nadi } \\
\text { menunjukkan adanya asosiasi } \\
\text { independen dengan mortalitas pada } \\
\text { ESI tingkat } 3 \text {, dengan kemampuan } \\
\text { prediksi yang sederhana } \\
\text { (Torabi et al., 2016) }\end{array}$ \\
\hline 5 & $\begin{array}{l}\text { Soon Y.K, Ki } \\
\text { J.H, Sang D.S, } \\
\text { Young S.R, Ki } \\
\text { O.A, Yu J.K, } \\
\text { Eui J.L } \\
2016\end{array}$ & $\begin{array}{l}\text { Validation of } \\
\text { the Shock } \\
\text { Index, } \\
\text { Modified } \\
\text { Shock Index, } \\
\text { and Age } \\
\text { Shock Index } \\
\text { for Predicting } \\
\text { Mortality of } \\
\text { Geriatric } \\
\text { Trauma } \\
\text { Patients in } \\
\text { Emergency } \\
\text { Departments }\end{array}$ & $\begin{array}{l}\text { Level 3.c } \\
\text { Cohort study } \\
\text { with control } \\
\text { group }\end{array}$ & $\begin{array}{l}\text { Tujuan dari } \\
\text { penelitian ini adalah } \\
\text { untuk memvalidasi } \\
\text { kekuatan SI, MSI, } \\
\text { dan Age SI sebagai } \\
\text { prediksi mortalitas } \\
\text { pada pasien trauma } \\
\text { geriatrik }\end{array}$ & $\begin{array}{l}\text { Design: Kohort } \\
\text { retrospektif, observasi } \\
\text { study } \\
\text { Sample: } 45.880 \text {, pasien } \\
\text { trauma di ED } \\
\text { menggunakan database } \\
\text { EDIIS yang merupakan } \\
\text { data cedera nasional yang } \\
\text { mencakup semua pasien } \\
\text { yang cedera dirawat di ED } \\
\text { di seluruh korea } \\
\text { Data Analysis: Analisis } \\
\text { deskriptif, membandingkan } \\
\text { variabel menggunakan uji }\end{array}$ & $\begin{array}{l}\text { Kekuatan statistik SI, MSI, dan Age } \\
\text { SI untuk memprediksi mortalitas } \\
\text { pasien trauma geriatrik dengan } \\
\text { menggunakan database EDIIS, yakni } \\
0,674 \text { untuk SI, } 0,682 \text { untuk MSI, } \\
\text { dan 0,740 untuk Age SI } \\
\text { (Kim et al., 2016) }\end{array}$ \\
\hline
\end{tabular}




\begin{tabular}{|c|c|c|c|c|c|c|}
\hline & & & & & $\begin{array}{l}\text { wilcoxon dan uji } \mathrm{x}^{2} \text {, } \\
\text { menghitung kurva } \\
\text { AUROC menilai daya } \\
\text { prediktif dan analisis } \\
\text { sensitivitas dari } 3 \\
\text { parameter tersebut } \\
\text { Instrumen: Lembar } \\
\text { Observasi }\end{array}$ & \\
\hline 6 & $\begin{array}{l}\text { Mohammad G, } \\
\text { Aly M.S, } \\
\text { Mohammad } \\
\text { M.A } \\
2016\end{array}$ & $\begin{array}{l}\text { Modified } \\
\text { Shock Index } \\
\text { as a predictor } \\
\text { of in Hospital } \\
\text { outcome in } \\
\text { cases of ST- } \\
\text { Segment } \\
\text { Elevation } \\
\text { Myocardial } \\
\text { Infarction } \\
\text { Treated with } \\
\text { Primary } \\
\text { Percutaneous } \\
\text { Coronary } \\
\text { Intervention }\end{array}$ & $\begin{array}{l}\text { Level 3.c } \\
\text { Cohort study } \\
\text { with control } \\
\text { group }\end{array}$ & $\begin{array}{l}\text { Untuk mengetahui } \\
\text { apakah SI dan MSI } \\
\text { dapat memprediksi } \\
\text { outcome dan MACE } \\
\text { pada pasien dengan } \\
\text { STEMI dirawat oleh } \\
\text { PPCI }\end{array}$ & $\begin{array}{l}\text { Design: Kohort prospektif, } \\
\text { observasi study } \\
\text { Sample: } 216 \text { responden, } \\
\text { Data Analysis: Uji } \\
\text { Wilcoxon, uji chi square } \\
\text { untuk penyajian variabel } \\
\text { kategori dalam bentuk } \\
\text { presentase } \\
\text { Instrumen: Lembar } \\
\text { Observasi }\end{array}$ & $\begin{array}{l}\text { SI dan MSI menjadi tanda awal } \\
\text { ketidakstabilan hemodinamik yang } \\
\text { dapat mengarah ke kondisi syok } \\
\text { kardiogenik. } \\
\text { SI dan MSI dapat memprediksi } \\
\text { mortalitas dan MACE pada pasien } \\
\text { dengan STEMI, namun bila } \\
\text { dibandingkan MSI merupakan faktor } \\
\text { independen yang kuat dalam } \\
\text { memprediksi outcome pasien dengan } \\
\text { STEMI } \\
\text { (Gouda, Saad, \& Daydamony, 2016) }\end{array}$ \\
\hline 7 & $\begin{array}{l}\text { Sebastian J.R, } \\
\text { George F, } \\
\text { Charlotte E, } \\
\text { Suzanne W, } \\
\text { Steffen D, } \\
\text { Bernhard M, } \\
\text { Gerhard S, } \\
\text { Holger T, Ingo } \\
\text { E } \\
2016\end{array}$ & $\begin{array}{l}\text { Shock Index } \\
\text { as a Predictor } \\
\text { of Myocardial } \\
\text { Damage and } \\
\text { Clinical } \\
\text { Outcome in } \\
\text { ST-Elevation } \\
\text { Myocardial } \\
\text { Infraction }\end{array}$ & $\begin{array}{l}\text { Level 3.c } \\
\text { Cohort study } \\
\text { with control } \\
\text { group }\end{array}$ & $\begin{array}{l}\text { Untuk mengevaluasi } \\
\text { hubungan Shock } \\
\text { Indeks (SI) sebagai } \\
\text { penanda kerusakan } \\
\text { miokard dan hasil } \\
\text { klinis pada pasien } \\
\text { dengan STEMI }\end{array}$ & $\begin{array}{l}\text { Design: Kohort } \\
\text { retrospektif, observasi } \\
\text { study } \\
\text { Sample: } 791 \text { rekam medis, } \\
\text { Data Analysis: } \\
\text { Menggunakan uji t tidak } \\
\text { berpasangan atau Mann- } \\
\text { Whitney digunakan untuk } \\
\text { menentukan perbedaan } \\
\text { variebal kontinu antar } \\
\text { kelompok. } \\
\text { Uji chi square digunakan } \\
\text { untuk membandingkan } \\
\text { variabel kategori antar } \\
\text { kelompok } \\
\text { Instrumen: Lembar } \\
\text { Observasi }\end{array}$ & $\begin{array}{l}\text { Shock Indeks (SI) merupakan } \\
\text { parameter yang sangat sederhana dan } \\
\text { obyektif yang dapat membantu } \\
\text { mengidentifikasi secara akurat } \\
\text { pasien STEMI yang beresiko } \\
\text { (Reinstadler et al., 2016) }\end{array}$ \\
\hline 8 & $\begin{array}{l}\text { Dana B, Zuzana } \\
\text { M, Petr W, } \\
\text { Jaroslav D, } \\
\text { Libor L, Tomas } \\
\text { B } \\
2011\end{array}$ & $\begin{array}{l}\text { Shock Index: } \\
\text { A Simple } \\
\text { Clinical } \\
\text { Parameter for } \\
\text { Quick } \\
\text { Mortality Risk } \\
\text { Assessment in } \\
\text { Acute } \\
\text { Myocardial } \\
\text { Infarction }\end{array}$ & $\begin{array}{l}\text { Level 3.c } \\
\text { Cohort study } \\
\text { with control } \\
\text { group }\end{array}$ & $\begin{array}{l}\text { Untuk mengetahui } \\
\text { hubungan Shock } \\
\text { Indeks (SI) dengan } \\
\text { prognosis pasien } \\
\text { sebagai indikator } \\
\text { resiko mortalitas } \\
\text { pada pasien Infark } \\
\text { Miokard Akut }\end{array}$ & $\begin{array}{l}\text { Design: Kohort } \\
\text { retrospektif, observasi } \\
\text { study } \\
\text { Sample: } 644 \text { rekam medis, } \\
\text { Data Analysis: } 2 \text {-sample } \\
\text { t-test untuk mengevaluasi } \\
\text { perbandingan antara } \\
\text { kelompok, perbedaan } \\
\text { proporsi antara kelompok } \\
\text { dianalisis dengan uji } \\
\text { Fisher exact test } \\
\text { Instrumen: Lembar } \\
\text { Observasi }\end{array}$ & $\begin{array}{l}\text { SI berkorelasi } \\
\text { dengan prognosis pasien, sehingga } \\
\text { dapat digunakan sebagai indikator } \\
\text { sederhana dari risiko mortalitas pada } \\
\text { pasien infark miokard akut. } \\
\text { (Bilkova et al., 2011) }\end{array}$ \\
\hline
\end{tabular}

Tabel 2. Deskripsi Studi

\begin{tabular}{|c|c|c|c|c|c|c|}
\hline Author \& Year & Sampel & Variabel & Usia & $\begin{array}{c}\text { Jenis } \\
\text { Kelamin }\end{array}$ & Outcome & Mortalitas \\
\hline $\begin{array}{l}\text { Yecheng L, Jihai L, Zhe } \\
\text { A.F, Guang L.S, Jun X, } \\
\text { Zhi W, Hua Z, Zhong W, } \\
\text { Xue Y }\end{array}$ & $\begin{array}{l}22.161 \\
\text { STEMI }\end{array}$ & $\begin{array}{l}\text { MSI : } \\
<0,7 \\
>1,3\end{array}$ & $45 \pm 19$ & L: $41 \%$ & $\begin{array}{l}\text { Penerimaan } \\
\text { ICU }\end{array}$ & $\begin{array}{l}\text { OR: } 3.7,95 \% \text { CI: } 1.7-7.8 \\
\text { OR: } 4.9,95 \% \text { CI: } 3.6-6.6\end{array}$ \\
\hline 2012 & & $\begin{array}{l}\text { SI : } \\
<0.5 \text { atau }>0.9\end{array}$ & & & $\begin{array}{l}\text { Penerimaan } \\
\text { ICU }\end{array}$ & OR: $1.3,95 \%$ CI: $0.8-1.7$ \\
\hline
\end{tabular}


Vol. 2, No. 2, July, 2020

\begin{tabular}{|c|c|c|c|c|c|c|}
\hline & & $\begin{array}{l}\text { Nadi : } \\
>120\end{array}$ & & & Penerimaan & OR: $2.6,95 \%$ CI: $1.9-3.6$ \\
\hline & & $\begin{array}{l}\text { Tekanan Darah: } \\
\text { SBP }<90 \\
\text { DBP }<60\end{array}$ & & & $\begin{array}{l}\text { Penerimaan } \\
\text { ICU }\end{array}$ & OR: $1.6,95 \%$ CI: $1.2-2.1$ \\
\hline \multirow[t]{2}{*}{$\begin{array}{l}\text { Qing S, Jing S.X, Hai S, } \\
\text { Ju Xiang L, Wenying W, } \\
\text { Kui H, Xiao S.C }\end{array}$} & 160 STEMI & $\begin{array}{l}\text { MSI } \\
1,4 \\
>1,4\end{array}$ & $\begin{array}{l}63,9 \pm 12,9 \\
69,0 \pm 13,0\end{array}$ & $\begin{array}{l}\text { L: } 92 \\
(82,9 \%) \\
\text { L: } 40 \\
(81,6 \%)\end{array}$ & $\begin{array}{l}\text { Serangan } \\
\text { jantung } \\
\text { OR: } 3.0,95 \% \\
\text { CI: } 0.8-11.9\end{array}$ & $\begin{array}{l}4(3,6 \%) \\
10(20,4 \%)\end{array}$ \\
\hline & & $\begin{array}{l}\text { SI } \\
0,7 \\
>0,7\end{array}$ & $\begin{array}{l}64,5 \pm 13,0 \\
66,6 \pm 13,4\end{array}$ & $\begin{array}{l}\text { L: } 73 \\
(83.0 \%) \\
\text { L: } 59 \\
(81,9 \%)\end{array}$ & $\begin{array}{l}\begin{array}{l}\text { Serangan } \\
\text { jantung }\end{array} \\
\text { OR: } 1.6,95 \% \\
\text { CI: } 0.4-6.0\end{array}$ & $\begin{array}{l}4(4,5 \%) \\
10(13,9 \%)\end{array}$ \\
\hline \multirow[t]{4}{*}{$\begin{array}{l}\text { Mehdi T, Amirhossein M, } \\
\text { Azam R, Neda S }\end{array}$} & 1285 & MSI & $57,72 \pm 20,29$ & $\begin{array}{l}\text { L: } 56 \% \\
\text { P: } 44 \%\end{array}$ & $\begin{array}{l}\text { Penerimaan } \\
\text { ICU } \\
\text { OR: } 1.05,95 \% \\
\text { CI: } 1.00-1.10\end{array}$ & OR: $1.08,95 \%$ CI: $1.04-1.11$ \\
\hline & & SI & & & $\begin{array}{l}\text { Penerimaan } \\
\text { ICU } \\
\text { OR: } 1.01,95 \% \\
\text { CI: } 1.00-1.01\end{array}$ & OR: $1.09,95 \%$ CI: $1.04-1.14$ \\
\hline & & Nadi & & & $\begin{array}{l}\text { Penerimaan } \\
\text { ICU } \\
\text { OR: } 0.99,95 \% \\
\text { CI: } 0.99-1.003\end{array}$ & OR: $0.99,95 \%$ CI: $0.99-1.003$ \\
\hline & & $\begin{array}{l}\text { Tekanan Darah } \\
\text { SBP } \\
\text { DBP }\end{array}$ & & & $\begin{array}{l}\text { Penerimaan } \\
\text { ICU } \\
\text { OR: } 0.99,95 \% \\
\text { CI: } 0.98-0.99 \\
\text { OR: } 0.98,95 \% \\
\text { CI: } 0.97-0.98\end{array}$ & $\begin{array}{l}\text { OR: } 0.99,95 \% \text { CI: } 0.98-0.99 \\
\text { OR: } 0.98,95 \% \text { CI: } 0.97-0.98\end{array}$ \\
\hline \multirow[t]{4}{*}{$\begin{array}{l}\text { Mehdi T, Shahrz M, } \\
\text { Amirhossein M, Azam R, } \\
\text { Neda S }\end{array}$} & 3375 & MSI & $54,4 \pm 19,6$ & & $\begin{array}{l}\text { Penerimaan } \\
\text { ICU } \\
\text { OR: } 1.12,95 \% \\
\text { CI: } 0.94-1.33\end{array}$ & OR: $1.22,95 \%$ CI: $1.10-1.35$ \\
\hline & & SI & & & $\begin{array}{l}\text { Penerimaan } \\
\text { ICU } \\
\text { OR: } 1.13,95 \% \\
\text { CI: } 0.90-1.42\end{array}$ & OR: $1.31,95 \%$ CI: $1.14-1.50$ \\
\hline & & Nadi & & & $\begin{array}{l}\text { Penerimaan } \\
\text { ICU } \\
\text { OR: } 0.98,95 \% \\
\text { CI: } 0.96-1.01\end{array}$ & OR: $0.96,95 \%$ CI: $0.95-0.98$ \\
\hline & & $\begin{array}{l}\text { Tekanan Darah } \\
\text { SBP } \\
\text { DBP }\end{array}$ & & & $\begin{array}{l}\text { Penerimaan } \\
\text { ICU } \\
\text { OR: } 0.97,95 \% \\
\text { CI: } 0.95-0.99 \\
\text { OR: } 0.96,95 \% \\
\text { CI: } 0.93-0.99\end{array}$ & $\begin{array}{l}\text { OR: } 0.97,95 \% \text { CI: } 0.95-0.98 \\
\text { OR: } 0.96,95 \% \text { CI: } 0.94-0.98\end{array}$ \\
\hline
\end{tabular}


Tabel 3. $\quad$ Deskripsi Shock Index (SI) dan Modified Shock Index (MSI) sebagai prediktor Outcome pada Pasien Darurat

\begin{tabular}{|c|c|c|}
\hline Author \& Year & $\begin{array}{l}\text { Paramater \& } \\
\text { Sampel }\end{array}$ & Outcome \\
\hline $\begin{array}{l}\text { Mohammad G, Aly M.S, } \\
\text { Mohammad M.A } \\
2016\end{array}$ & $\begin{array}{l}\text { Modified Shock } \\
\text { Index (MSI) } \\
216 \text { STEMI }\end{array}$ & $\begin{array}{l}\text { 1. Prediksi mortalitas } \\
\text { OR 5,599; 95\% CI 4.128-8,15; } \mathrm{p}=0,015 \\
\text { 2. Prediksi MACE (Major Adverse Cardiac Events) } \\
\text { OR } 11.506 ; 95 \% \text { CI } 10.54-21.5664 ; \mathrm{p}=0,022\end{array}$ \\
\hline $\begin{array}{l}\text { Sebastian J.R, George F, } \\
\text { Charlotte E, Suzanne W, } \\
\text { Steffen D, Bernhard M, } \\
\text { Gerhard S, Holger T, Ingo } \\
\text { E }\end{array}$ & $\begin{array}{c}\text { Shock Index (SI) } \\
791 \text { STEMI }\end{array}$ & $\begin{array}{l}\text { 1. SI : } \geq 0.62 \text {, sensivitas } 66 \% \text {, spesifisitas } 61 \% \text {, artinya memiliki infark yang } \\
\text { jauh lebih besar, cedera reperfusi lebih parah dan akibatnya fraksi ejeksi } \\
\text { LV lebih berkurang, berada pada resiko tinggi untuk MACE } \\
\text { 2. SI penanda risiko yang akurat dan mudah untuk penilaian awal terjadinya } \\
\text { syok kardiogenik }\end{array}$ \\
\hline 2016 & & \\
\hline $\begin{array}{l}\text { Dana B, Zuzana M, Petr } \\
\text { W, Jaroslav D, Libor L, } \\
\text { Tomas B }\end{array}$ & $\begin{array}{l}\text { Shock Index (SI) } \\
644 \text { IMA }\end{array}$ & $\begin{array}{l}\text { Prediksi Mortalitas ; } \\
\text { OR 81.26; 95\% CI 9.76-676.51; } \mathrm{p}=0.001\end{array}$ \\
\hline 2011 & & \\
\hline $\begin{array}{l}\text { Soon Y.K, Ki J.H, Sang } \\
\text { D.S, Young S.R, Ki O.A, } \\
\text { Yu J.K, Eui J.L } \\
2016\end{array}$ & $\begin{array}{l}\text { Modified Shock } \\
\text { Index, Shock Index } \\
\begin{array}{l}45.880 \text { pasien } \\
\text { trauma }\end{array}\end{array}$ & $\begin{array}{l}\text { Mortalitas di Departemen Gawat Darurat : } \\
\text { Shock Index 56,1 \%, AUROC curve } 0,674 \\
\text { Modified Shock Index 58,2 \%, AUROC curve } 0,682\end{array}$ \\
\hline
\end{tabular}

\section{Pembahasan}

Shock Indeks (SI) adalah perhitungan sederhana Heart Rate (HR) dibagi dengan tekanan darah sistolik (SBP), didapatkan nilai normal SI biasanya 0,5 sampai 0,7 . SI merupakan indikator yang baik dalam mendiagnosa kondisi akut hipovolemi dan mengidentifikasi disfungsi pada ventrikel kiri (Robert, Gaeta, Terry, Bove, \& John, 2005). Penelitian yang dilakukan pada pasien trauma didapatkan hasil SI > 0,9 menunjukkan peningkatan resiko kematian sebesar $12,8 \%$ dibandingkan SI < 0,9 yaitu $6,1 \%$, sehingga disimpulkan bahwa SI adalah prediktor yang baik dalam menentukan kematian pada 48 jam pertama dibandingkan hanya menggunakan SBP dan HR (Zarzaur, Croze, Fischer, Magnotti, \& Fabian, 2008). Sedangkan (Montoya, Charry,
Calle, N'unez, \& Poveda, 2015) mengatakan bahwa SI > 0,9 berkolerasi dengan kematian pada $<24$ jam lebih awal $(59,5 \%)$

MSI merupakan nilai yang didapatkan dari Heart Rate (HR) dibagi dengan Mean Arterial Pressure (MAP), didapatkan nilai normal MSI biasanya 0,7 sampai 1,3 . Nilai MSI yang meningkat mengindikasikan nilai stroke volume dan resistensi pembuluh darah sistemik rendah, mencerminkan keadaan sirkulasi hipodinamik, pasien dapat kompensasi dan dekompensasi yang cepat. Sedangkan jika nilai MSI menurun menunjukkan bahwa SI dan Systemic Vascular Resistance (SVR) tinggi, pasien dalam keadaan hiperdinamik, yang menandakan kondisi yang serius. Dan nilai MSI memprediksi 
tingkat mortalitas secara signifikan lebih baik daripada denyut jantung, tekanan darah sistolik, DBP dan SI (Singh et al., 2014).

Penelitian saat ini menunjukkan bahwa SI dan MSI merupakan parameter yang dapat digunakan dalam pemeriksaan status hemodinamik pasien. Semua studi yang disertakan menunjukkan SI dan MSI, memiliki nilai yang dapat mengidentifikasi outcome pasien darurat dan dapat dijadikan sebagai prediktor mortalitas. Hasil penelitian didapatkan nilai SI $<0.5$ atau >0.9 sebagai prediktor mortalitas pasien darurat (OR: 1.3, 95\% CI: 0.8-1.7), nilai MSI yang lebih besar dari 1,3 diindikasikan pasien masuk ruang ICU. Selain itu, MSI >1,3 merupakan prediktor peningkatan mortalitas (OR: 4.9, 95\% CI: 3.6-6.6). Hal ini sering terlihat pada pasien dengan penyakit serebrovaskular, nyeri dada dan jantung berdebar. Nadi $>120$ dikatakan sebagai prediktor mortalitas pada pasien darurat (OR: 2.6, 95\% CI: 1.93.6). Sedangkan untuk tekanan darah dengan nilai SBP <90, DBP <60 (OR: 1.6, 95\% CI: 1.2-2.1). Sehingga disimpulkan bahwa SI dan MSI merupakan prediktor klinis yang lebih baik dari pada nadi dan tekanan darah (Liu et al., 2012).

Penelitian yang dilakukan (Torabi et al., 2015), didapatkan SI untuk perkiraan perawatan di ICU (OR: 1.01, 95\% CI:
1.00-1.01), prediktor mortalitas (OR: 1.09, 95\% CI: 1.04-1.14), MSI untuk perkiraan perawatan di ICU (OR: 1.05, 95\% CI: 1.00-1.10), prediktor mortalitas (OR: 1.08, 95\% CI: 1.04-1.11), Nadi untuk perkiraan perawatan di ICU (OR: 0.99, 95\% CI: 0.99-1.003), prediktor mortalitas (OR: 0.99, 95\% CI: 0.99-1.003) dan tekanan darah untuk perkiraan perawatan di ICU (OR: 0.99, 95\% CI: 0.98-0.99), prediktor mortalitas (OR: 0.99, 95\% CI: 0.98-0.99). Penggunaan SI dan MSI menunjukkan keunggulan yang jelas atas nadi dan tekanan darah. Sehingga hal ini perlu dijadikan tambahan pemeriksaan status hemodinamik pasien untuk prognosis pasien ditriase.

Penggunaan parameter SI dan MSI sebagai prediktor outcome pasien STEMI, penelitian oleh (Reinstadler et al., 2016) dengan jumlah sampel 791 didapatkan SI dengan nilai $\geq 0.62$, memiliki sensivitas $66 \%$, spesifisitas $61 \%$, artinya memiliki infark yang jauh lebih besar, cedera reperfusi lebih parah dan akibatnya fraksi ejeksi LV lebih berkurang.SI penanda risiko yang akurat dan mudah untuk penilaian awal terjadinya syok kardiogenik dan dapat mengidentifikasi terjadinya MACE. Sedangkan penelitian oleh (Gouda et al., 2016), dengan jumlah sampel 216 didapatkan MSI dapat memprediksi MACE (Major Adverse Cardiac Events) 
dengan hasil statistik (OR 11.506; 95\% CI

10.54-21.5664; $\mathrm{p}=0,022$ )

\section{Kesimpulan}

SI dan MSI signifikan berkorelasi dengan penanda resiko yang akurat, berupa kematian klinis pada pasien dengan kondisi darurat dan lebih baik dari pada tekanan darah dan detak jantung. Sehingga SI dan MSI dapat direkomendasikan sebagai paramater non invasif guna mendeteksi lebih awal status hemodinamik pasien dan dapat digunakan dalam triase pasien di ruang gawat darurat.

\section{Daftar Pustaka}

Bilkova, D, Motovska, Z, Widimsky, P, Dvorak, J, Lisa, L, \& Budesinsky, T. (2011). Shock Index: A Simple Clinical Parameter for Quick Mortality Risk Assessment in Acute Myocardial Infarction. Canadian Journal of Cardiology, 27, 739-742. doi: 10.1016/j.cjca.2011.07.008

Birkhahn, R.H, Gaeta, T.J, Terry, D, Bove, J.J, \& Tloczkowski. (2005). Shock index in diagnosing early acute hypovolemia. American Journal of Emergency Medicine, 23(3), 323326.

Gouda, M, Saad, A.M, \& Daydamony, M. (2016). Modified Shock Index as a predictor of in Hospital outcome in cases of ST-Segment Elevation Myocardial Infarction Treated with Primary Percutaneous Coronary Intervention. Journal of Cardiology \& Current Research, 7(4).
Jevon, \& Ewens. (2009). Pemantauan Pasien Kritis. Jakarta: Erlangga.

Kim, S.Y, Hong, K.J, Shin, S.D, Ro, Y.S, Ahn, K.O, Kim, Y.J, \& Lee, E.J. (2016). Validation of the Shock Index, Modified Shock Index, and Age Shock Index for Predicting Mortality of Geriatric Trauma Patients in Emergency Departments. Journal Korean Academy of Medical Sciences, 3(1), 2026-2032. doi: 10.3346/jkms.2016.31.12.2026

Liu, Y, Liu, J, Fang, Z.A, Shan, G.L, Xu, J, Qi, Z, . . . Yu, X.Z. (2012). Modified Shock Index and Mortality rate of emergency patient. World Journal of Emergency Medicine, 3(2), 114117.

Montoya, K.F, Charry, J.D, Calle, T.S, N'unez, L.R, \& Poveda, G. (2015). Shock index as a mortality predictor in patients with acute polytrauma. Journal of Acute Disease, 4(3), 202-204. doi: doi.org/10.1016/j.joad.2015.04.006

Reinstadler, S, Fuernau, G, Eitel, C, Waha, S, Desch, S, Metzler, B, . . . Eitel, I. (2016). Shock Index as a Predictor of Myocardial Damage and Clinical Outcome in STElevation Myocardial Infraction. Journal of the Japanese Circulation Society, 80, 924-930.

Robert, B.H, Gaeta, T.J, Terry, D, Bove, J.J, \& John, T. (2005). Shock indeks in diagnosing early acute hypovolemia. 323-326.

Shangguan, Q, Xu, J.S, Su, H, Li, J, Wang, W.Y, Hong, K, \& Cheng, X. (2015). Modified Shock Index is a Predictor for 7 Day Outcomes in Patients with STEMI. American Journal of Emergency Medicine, 1072-1075.

Singh, A, Ali, S, Agarwal, A, \& Srivastava, R.N. (2014). Correlation of Shock Index and 
Modifi ed Shock Index with the

Outcome of Adult Trauma

Patients: A Prospective Study of

9860 Patients. North American

Journal of Medical Sciences, 6(9).

Torabi, M, Mirafzal, A, Rastegari, A, \&

Sadeghkhani, N. (2015).

Association of triage time Shock

Index, Modified Shock Index, and

Age Shock Index with mortality in

Emergency Severity Index level 2

patients. American Journal of

Emergency Medicine, 3(4), 63-68.

Torabi, M, Mirafzal, A, Rastegari, A, \&

Sadeghkhani, N. (2016). Shock

Index, Modified Shock Index, and

Age Shock Index for prediction of

mortality in Emergency Severity

Index level 3. American Journal of

Emergency Medicine. doi:

10.1016/j.ajem.2016.07.017

Zarzaur, B.L, Croze, M, Fischer,

P.E,Magnotti, L.J, \& Fabian, T.C.

(2008).New vitals after injury:

shock index for the young and age

$\mathrm{x}$ shoxk index for the old. $J$ Surg

Res, 229-236. 